\title{
Boarding House Selection using SAW Method
}

\author{
Hamid Mukhlis, B. Ayshwarya, Phong Thanh Nguyen, Wahidah Hashim, Hardono, Siti \\ Maesaroh, Yona Desni Sagita, Surmiasih, Rido Sanjaya, Oktafianto, K. Shankar, Oksana P. \\ Denisova, Andino Maseleno
}

\begin{abstract}
Determination of residence in a new area known is influenced by many factors namely location, facilities, contract systems and prices. This journal determines the criteria used in selecting a residence. These criteria were analyzed using simple additive weighting (SAW) method. The results of the analysis obtained in the form of location criteria to determine the most suitable boarding house because the existence of boarding houses in the vicinity of public facilities is highly expected for migrants in a new area. With the advancement of information technology it can answer the need to find a boarding house, and will be very helpful both from the owner and tenant side. And not only that, with this internet technology, prospective tenants can also select a boarding house that suits their wishes. Planning a system that can assist in the determination of temporary housing is needed by tenants in finding housing that fits the desired criteria. With the creation of a DSS (Decision Support System), the selection of boarding houses is expected to help resolve the problem of alternative housing. Therefore a decision support system application program is needed to determine a temporary residence or boarding house. Decision support system is a computer-based system that aims to assist decision making by utilizing data and models to solve unstructured problems.
\end{abstract}

Index Terms: Location, analysis criteria, decision support system, Simple Additive Weighting

Revised Manuscript Received on July 22, 2019.

Hamid Mukhlis, Universitas Aisyah Pringsewu, Lampung, Indonesia.

B. Ayshwarya, Department of Computer Science, Kristu Jayanti College, Bangalore-560043, India.

Phong Thanh Nguyen, Department of Project Management, Ho Chi Minh City Open University (HCMCOU), Vietnam.

Wahidah Hashim, Institute of Informatics and Computing Energy, Universiti Tenaga Nasional, Malaysia.

Hardono, Universitas Aisyah Pringsewu, Lampung, Indonesia.

Siti Maesaroh, Universitas Aisyah Pringsewu, Lampung, Indonesia.

Yona Desni Sagita, Universitas Aisyah Pringsewu, Lampung, Indonesia.

Surmiasih, Universitas Aisyah Pringsewu, Lampung, Indonesia.

Rido Sanjaya, Department of Information Systems, STMIK Pringsewu, Lampung, Indonesia.

Oktafianto, Institute Teknologi Sumatera, Lampung, Indonesia.

K. Shankar, School of Computing, Kalasalingam Academy of Research and Education, Krishnankoil, India.

Oksana P. Denisova, Togliatti State University, Russia Andino Maseleno, Institute of Informatics and Computing Energy, Universiti Tenaga Nasional, Malaysia. E-mail: andimaseleno@gmail.com

\section{INTRODUCTION}

\section{A. Background}

The issue of decision making is basically a form of selection of various alternative actions that may be selected which process through a certain mechanism, with the desire that it will produce the best decisions such as the existence of a less accurate boarding house that becomes difficult at the beginning for new arrivals [1-5]. With the existence of internet technology, it allows the owners of boarding houses to promote their boarding houses through this medium at a relatively cheap cost [6-10] and can be seen directly by prospective tenants using the Simple Additive Weighting (SAW) method on a decision support system that is one way of solving problems, where consumers will feel helped by the existence of this system by providing recommendations or suggestions for boarding places that are in accordance with consumer criteria by inputting criteria on the system by users [11][12]. So that at the end of the process users will get a list of recommended boarding house based on their input criteria. The results showed that this boarding house search system can help prospective boarding tenants to get alternative boarding places that can be recommended based on the selected criteria.

\section{B. Problem Formulation}

Based on background above it can be formulated problem to be solved, it was how to design a decision support system using Simple Additive Weighting (SAW) to determine boarding house selection criteria.

\section{Problem Limitation}

1. Research was conducted in boarding house around Pringsewu market.

2. This application system is built to make decision in selecting boarding house around Pringsewu market.

3. Decision making system was made only to give boarding house alternative rent with the number of options is five boarding houses

4. This decision support system was made by using PHP and MySQL programing language as database.

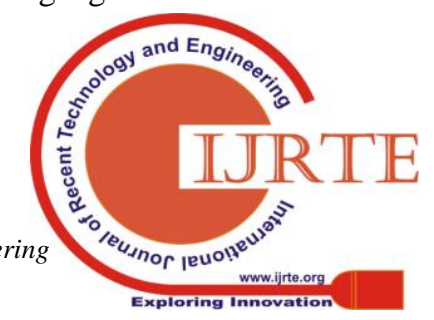




\section{Research Objective}

To produce decision support system to determine boarding house using Simple Additive Weighting (SAW).

\section{LITERATURE REVIEW}

\section{A. System}

The system is a network of interconnected procedures collect together to carry out an activity for a particular purpose [13-16]. The system in general is a collection of elements that interact with each other to achieve a goal [17-20].

\section{B. Information}

Data and information is a foundation in understanding information system [21-24]. Information is processed data and meaningful data [25-28].

\section{Information System}

Information is a computerized system for processing data entered into information or data, storing, distributing and producing new information to complete a task automatically or as a supporter of human resources in carrying out the functions of corporate operations, controlling and returning decisions within an organization [29-32]. Information is a group of interconnected component and functions to collect, process and provide output in the form of information needed to finish business duties [33-36].

\section{D.Boarding house definition}

Boarding house (bahasa: kost) is a service that offers a room or place to live in with a certain amount of payment for each particular period (generally costs). The word "kost" is actually a derivative of the Dutch phrase "Indekost". "But if the phrase is further elaborated can also mean "stay and eat" inside the house. Often the time goes on and age changes, now the public in Indonesia calls the term "indekost" by abbreviating it as "kost" only This boarding service is not free, that is with certain payments for each period, usually calculated monthly.

\section{E.Simple Additive Weighting (SAW)}

SAW Method is looking for a weighted addition from the performance rating on each alternative on all attributes. SAW Method Required a normalization process decision matrix (X) to a scale which can be compared with all available alternative ratings

\section{RESEARCH METHOD}

\section{A.Observastion}

Observation in the context of scientific research is a study that is endured and carried out systematically, planned and directed at a goal by observing and recording the phenomenon or behavior of a group of people in context in daily life and pay attention to daily life and show scientific research requirements [37-40]. Thus the results can be accounted for the truth.

\section{B. Literature Research Method}

Library method is data collection techniques by learning references in the form of documents / files and data collection, legislation, books, research journals, etc., through library research was reviewed the laws and regulations related to the management of regional potential. Need of data revealed about indicators used by investors for decision making investment was obtained through library research towards research books and journals. Library study was also conducted to know technology capabilities information that will be applied in system.

\section{DESIGN AND IMPLEMENTATION}

Several things that can be described are as follows

\section{A. Design}

This performance assessment of decision support system was used to determine the performance of the selection of boarding house. The stage of making this application, first, determine and plan the criteria in determining the boarding house, namely costs, distance, facilities, and room area.

\section{a. Weight}

In this research there were weight and criteria needed to determine boarding house selection.

Table 1. Criteria code.

\begin{tabular}{|c|l|}
\hline Criteria code & Description \\
\hline C1 & Cost \\
\hline C2 & Distance \\
\hline C3 & Facility \\
\hline C4 & Room size \\
\hline
\end{tabular}

From the criteria, it can be determined the importance level of criteria based on weight score determined in fuzzy number. Suitability rating of each alternative of each criterion is as follows: table 2 shows location criteria, table 3 shows cost criteria, table 4 shows distance criteria, table 5 shows facility criteria, table 6 shows room size criteria.

Table 2. Location criteria

\begin{tabular}{|l|l|}
\hline \multicolumn{1}{|c|}{ Location criteria } & Score \\
\hline Close to market (DP) & 1 \\
\hline Close to road (DJR) & 2 \\
\hline Close to worship place (DTP) & 3 \\
\hline Close to restaurant (DRM) & 4 \\
\hline Close to entertainment area (DTH) & 5 \\
\hline
\end{tabular}

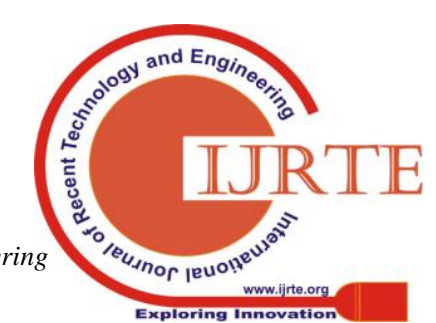


Table 3. Cost criteria

\begin{tabular}{|l|l|}
\hline \multicolumn{1}{|c|}{ Cost } & Score \\
\hline$\geq 700,000$ & 1 \\
\hline$>700,000<400,000$ & 2 \\
\hline$>400,000<350,000$ & 3 \\
\hline$>350,000<300,000$ & 4 \\
\hline$\leq 300,000$ & 5 \\
\hline
\end{tabular}

Table 4. Distance criteria

\begin{tabular}{|l|l|}
\hline Distance & Score \\
\hline$\geq 1 \mathrm{~km}$ & 1 \\
\hline$>1 \mathrm{~km}<700 \mathrm{~m}$ & 2 \\
\hline$>700 \mathrm{~m}<350 \mathrm{~m}$ & 3 \\
\hline$>350 \mathrm{~m} \leq 50 \mathrm{~m}$ & 4 \\
\hline$\leq 50 \mathrm{~m}$ & 5 \\
\hline
\end{tabular}

Table 5. Facility criteria

\begin{tabular}{|l|l|}
\hline \multicolumn{1}{|c|}{ Facility } & Score \\
\hline mattress & 1 \\
\hline mattress, wardrobe & 2 \\
\hline mattress, wardrobe, table & 3 \\
\hline mattress, wardrobe, table, fan & 4 \\
\hline mattress, wardrobe, table, fan, TV & 5 \\
\hline
\end{tabular}

Table 6. Room size criteria

\begin{tabular}{|l|l|}
\hline \multicolumn{1}{|c|}{ Room size } & Score \\
\hline $3 \times 4 \mathrm{~m} 2$ & 1 \\
\hline $4 \times 5 \mathrm{~m} 2$ & 2 \\
\hline $5 \times 6 \mathrm{~m} 2$ & 3 \\
\hline $6 \times 7 \mathrm{~m} 2$ & 4 \\
\hline $7 \times 8 \mathrm{~m} 2$ & 5 \\
\hline
\end{tabular}

b. System Design

Figure 1 shows DFD Level 1.

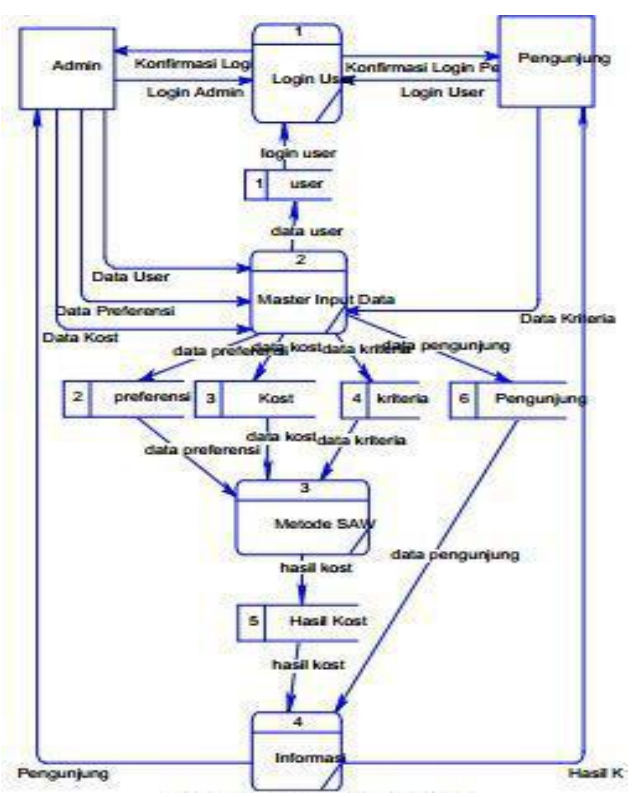

Figure 1. DFD Level 1 (admin- login confirmation - admin login - user login - visitoruser data - boarding house data - preference data - preference - boarding house - criteria - visitor - SAW method- boarding result-information)

At the figure 1. It can be known the outside entity involved was admin and visitor

\section{a) Admin}

Admin had some duties to input user data, cost data, criteria data and preference. Besides that admin can insert, update, delete each data form input.

1. As data manager with full access right

2. Having access right to insert, update, delete user data.

3. Having access right to insert, update and delete cost data.

4. Having access right to insert, update, and delete preference data.

5. Having access right to insert, update criteria data.

6. Viewing visitor data.

b) Visitor

Visitor selected boarding house based on input criteria

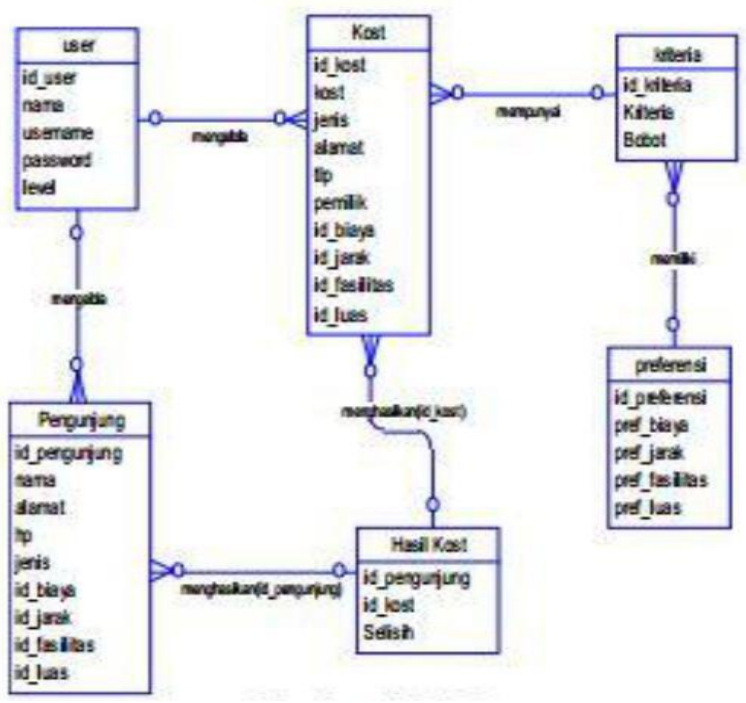

Figure 2. ERD

Figure 2 shows Entity Relationship Diagram (ERD). ERD from Decision Support System of Boarding House selection consisted of 6 tables namely user table, boarding house table, visitor table, boarding house result table, preference table and criteria table, the table is related each other.

\section{B. Implementation}

In this research, it would be an example of calculation in looking for boarding house from 3 boarding houses and 1 visitor. Decision making gave preference weight as follows : $\mathrm{W}=(4,3,2,2)$. Table 7 shows preference weight.

Table 7. Preference weight

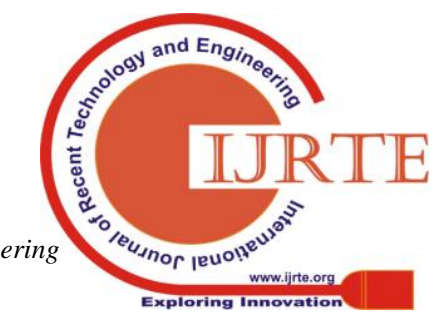




\begin{tabular}{|l|c|c|c|c|}
\hline \multirow{2}{*}{ Alternative } & \multicolumn{3}{|l|}{ Criteria } \\
\cline { 2 - 5 } & C1 & C2 & C3 & C4 \\
\hline Cost 1 & 5 & 5 & 3 & 2 \\
\hline Costt2 & 4 & 4 & 2 & 2 \\
\hline Cost 3 & 5 & 5 & 3 & 1 \\
\hline
\end{tabular}

Decision matrix formed was as follows :

$$
x_{\text {Kos }}=\left(\begin{array}{llll}
5 & 5 & 3 & 2 \\
4 & 4 & 2 & 2 \\
5 & 5 & 3 & 1
\end{array}\right)
$$

Matrix Normalization

Cost $1(\mathrm{~K} 1)$ :

$$
\begin{aligned}
& \mathrm{R} 11=\operatorname{Min}\{5,4,5\} / 5=4 / 5=0.8 \\
& \mathrm{R} 12=\operatorname{Min}\{5,4,5\} / 5=4 / 5=0.8 \\
& \mathrm{R} 13=3 / \operatorname{Max}\{3,2,3\}=3 / 3=1 \\
& \mathrm{R} 14=2 / \operatorname{Max}\{2,2,1\}=2 / 2=1
\end{aligned}
$$

Cost 2 (K2):

$\mathrm{R} 21=\operatorname{Min}\{5,4,5\} / 4=4 / 4=1$

$\mathrm{R} 22=\operatorname{Min}\{5,4,5\} / 4=4 / 4=1$

$\mathrm{R} 23=2 / \operatorname{Max}\{3,2,3\}=2 / 3=0.67$

$\mathrm{R} 24=2 / \operatorname{Max}\{2,2,1\}=2 / 2=1$

\section{Cost 3 (K3)}

$\mathrm{R} 31=\operatorname{Min}\{5,4,5\} / 5=4 / 5=0.8$

$\mathrm{R} 32=\operatorname{Min}\{5,4,5\} / 5=4 / 5=0.8$

$\mathrm{R} 33=3 / \operatorname{Max}\{3,2,3\}=3 / 3=1$

$\mathrm{R} 34=1 / \operatorname{Max}\{2,2,1\}=4 / 5=0.5$

Normalization of $\mathrm{R}$ matrix was obtained from normalization of $\mathrm{X}$ matrix as follows :

$$
\text { R Kost }=\left[\begin{array}{cccc}
0,8 & 0,8 & 1 & 1 \\
1 & 1 & 0,67 & 1 \\
0,8 & 0,8 & 1 & 0,5
\end{array}\right]
$$

Then it will be made multiplication of $\mathrm{W}^{*} \mathrm{R}$ and addition of multiplication result to obtain best alternative by performing greatest score ranking as follows :

$\mathrm{V} \operatorname{cost} 1=(0.8 * 4)+(0.8 * 3)+(1 * 2)+(1 * 2)=9.6$

$\mathrm{Vcost} 2=(1 * 4)+(1 * 3)+(0,67 * 2)+(1 * 2)=10.3$

$\mathrm{V} \operatorname{cost} 3=(0.8 * 4)+(0.8 * 3)+(1 * 2)+(0,5 * 2)=8.6$

Thus alternative (cost 1) was selected alternative as alternative cost that suitable with criteria.

\section{CONCLUSION AND SUGGESTION}

\section{A. Conclusion}

Concept of decision support system design of housing or boarding house is expected to be a reference for further development. From various boarding houses exist in Pringsewu, it is expected to help tenant in determining decent boarding house in accordance with desire from tenant.

\section{B. Suggestion}

To improve performance and complete decision support system made, author gives some suggestion as follows :

1. Because of time limitation, author only limited 4 scores of each criterion, namely cost,1 distance, facility and room size. For system development can be added other variable scores that is possible to reinforce in decision making.

2.Web-based system becomes the true development system to make the application can be accessed everywhere.

\section{REFERENCES}

[1]. Akhmetshin, E. M., Solodova, E. P., Selyutina, A. V., Sharafutdinov, R. I., \& Kulmetev, R. I. (2018). Directions of small business development in housing and communal services of samara region. Paper presented at the Proceedings of the 31st International Business Information Management Association Conference, IBIMA 2018: Innovation Management and Education Excellence through Vision 2020, 3924-3930.

[2]. Ibatova, A. Z. (2018). Implementation of ISO principles in engineers' training. International Journal of Civil Engineering and Technology, 9(3), 515-521.

[3]. Elena V. Smirnova, B. Ayshwarya, Phong Thanh Nguyen, Wahidah Hashim, Andino Maseleno, Using Shell Programs in Educational and Methodological Support for Learning Foreign Language, International Journal of Applied Exercise Physiology, Vol. 8 (2.1), 2019. pp. 1027-1032.

[4]. Inga E. Rakhimbaeva, Aleksandr A. Korostelev, Indira A. Shakirova, B. Ayshwarya, Phong Thanh Nguyen, Wahidah Hashim, Andino Maseleno, Integration of the Educational and Didactic Systems in the Training of Future Teachers, International Journal of Applied Exercise Physiology, Vol. 8 (2.1), 2019. pp. 1033-1038.

[5]. Alla L. Busygina, Elena M. Chertakova, Darya B. Shtrikova, B. Ayshwarya, Phong Thanh Nguyen, Wahidah Hashim, Andino Maseleno, Professional forms of Employment in the Russian Federation: Problems and Challenges, International Journal of Applied Exercise Physiology, Vol. 8 (2.1), 2019. pp. 1039-1045.

[6]. Olga I. Pugach, Andrei V. Ochepovsky, Wahidah Hashim, Andino Maseleno, B.Ayshwarya, Phong Thanh Nguyen, To the use of English Words When Learning Programming, Information Systems and Technologies, International Journal of Applied Exercise Physiology, Vol. 8 (2.1), 2019. pp. 1046-1051.

[7]. Narges Bahrami, Sifeng Liu, Vadim Vitalievich Ponkratov, Phong Thanh Nguyen, Andino Maseleno, Stephen Berti, Novel Load Management for Renewable Generation Sources/Battery System through Cut Energy Expenditure and Generate Revenue, International Journal of Ambient Energy, Taylor and Francis Online, 2019.

[8]. P. Uma Maheswari, P. Manickam, K. Sathesh Kumar, Andino Maseleno, K. Shankar, Bat optimization algorithm with fuzzy based PIT sharing (BF-PIT) algorithm for 
Named Data Networking (NDN), Journal of Intelligent \& Fuzzy Systems, IOS Press, pp. 1-8, 2019.

[9]. Grigory Olegovich Yarygin, Aleksandr Aleeksevich Korostelev, Rafis H. Mukhutdinov, Andino Maseleno, Elections and Russian Citizens Residing Overseas: Prospects for Internet Voting, International Journal of Recent Technology and Engineering (IJRTE), Vol. 7, Issue 6S5, pp. 52-57, 2019.

[10].Larisa Akhunzhanovna Apanasyuk, Elena Vladimirovna Smirnova, Rafis H. Mukhutdinov, Andino Maseleno, The Problem of the Organization of Socio-Cultural Environment for Adaptation and Development of a Student-Migrant's Bilingual Identity in the Conditions of the Russian Higher Education, International Journal of Recent Technology and Engineering (IJRTE), Vol. 7, Issue 6S5, pp. 63-70, 2019.

[11]. Abdul Hamid, Ajat Sudrajat, Razaleigh Muhamat Kawangit, Abdul Ghafar Don, Miftachul Huda, Burhanuddin Jalal, Wahyu Akbar, Azura Onn, Andino Maseleno, Determining basic food quality using SAW, International Journal of Engineering and Technology(UAE), Vol. 7, No. 4, pp. 3548-3555, 2018.

[12]. Satria Abadi, Miftachul Huda, Kamarul Shukri Mat Teh, Zulkiflee Haron, Mohd. Nasir Ripin, Aminudin Hehsan, Shamsul Sarip, Muhamad Rafiqi Hehsan, Musfika Amrullah, Andino Maseleno, Hazard Level of Vehicle Smoke by Fuzzy Multiple Attribute Decision Making with Simple Additive Weighting Method, International Journal of Pharmaceutical Research, Vol. 10, Issue 4, 2018.

[13]. Alla L. Busygina, Liliya A. Meteleva, Darya B. Shtrikova, Rafis H. Mukhutdinov, Andino Maseleno, Bases of Formation of Women's Professional Mentality in Russia, International Journal of Recent Technology and Engineering (IJRTE), Vol. 7, Issue 6S5, pp. 71-77, 2019.

[14]. Oleg N. Yarygin, Aleksandr A. Korostelev, Linar G. Akhmetov, Andino Maseleno, Modeling of Competence as a Tool of Goal Setting for Education in Modern Society, International Journal of Recent Technology and Engineering (IJRTE), Vol. 7, Issue 6S5, pp. 78-86, 2019.

[15]. Raven John, Aleksandr A. Korostelev, Oleg N. Yarygin, Rafis H. Mukhutdinov, Andino Maseleno, The Genesys and Base Concepts of Competentology, International Journal of Recent Technology and Engineering (IJRTE), Vol. 7, Issue 6S5, pp. 87-95, 2019.

[16].Bogdanova Anna Vladimirovna, Aleksandr Alekseevich Korostelev, Rafis H. Mukhutdinov, Indira A. Shakirova, Andino Maseleno, Formulation of the Problem of Mathematical Modeling of Accommodation of Basic Stations of Cellular Communication in Residential Territories for Students of It-Directions of Preparation, International Journal of Recent Technology and Engineering (IJRTE), Vol. 7, Issue 6S5, pp. 96-100, 2019.

[17]. Bogdanova A. Vladimirovna, Aleksandr A. Korostelev, Olga L. Shepelyuk, Anna E. Rodionova, Irina N. Fardeeva, Andino Maseleno, Reengineering of Business Processes of the Higher School: Its Prerequisites, International Journal of Recent Technology and Engineering (IJRTE), Vol. 7, Issue 6S5, pp. 101-104, 2019.

[18]. Rustem R. Vakhitov, Anna E. Rodionova, Elena V. Smirnova, Rafis H. Mukhutdinov, Mariya I. Arzhakova, Andino Maseleno, Crisis of Higher Education in Russia, International Journal of Recent Technology and Engineering (IJRTE), Vol. 7, Issue 6S5, pp. 105-109, 2019.

[19].Kuznetsov Sergey Vladimirovich, Magizov Rustem Robertovich, Radzevanovskaya Yuliya Viktorovna, Alexey V. Kuznetsov, Mukhametgaliev Iskandar Gabdulvaliyevich, Andino Maseleno, Public Anti-Corruption Control as a Mechanism to Counter Corruption in the Russian Federation, International Journal of Recent Technology and Engineering (IJRTE), Vol. 7, Issue 6S5, pp. 110-113, 2019.

[20].R. Fenny Syafariani, Andri Sahata Sitanggang, Andino Maseleno, Application of Backend and Frontend Systems on Go-Baby Application in Bandung City, International Journal of Recent Technology and Engineering (IJRTE), Vol. 7, Issue 6S5, pp. 125-131, 2019.

[21]. Natalia L. Ivanova, Nikolay Ivanovich Sinyavsky, Alexey Valerievich Fursov, Oksana Petrovna Denisova, Andino Maseleno, Future Oil and Gas Students' Attitude to Healthy Lifestyle and Their Participation in the Implementation of Russian Physical Educational Complex «Ready for Labor and Defense» (Rld) Normatives, International Journal of Recent Technology and Engineering (IJRTE), Vol. 7, Issue 6S5, pp. 186-189, 2019.

[22]. Natalia P. Nikonova, Larisa N. Gorina, Andino Maseleno, Cooperation between the European Union and the Eurasian Union, International Journal of Recent Technology and Engineering (IJRTE), Vol. 7, Issue 6S5, pp. 201-203, 2019.

[23]. Natalie P. Nikonova, Larisa N. Gorina, Andino Maseleno, Inter-Regional Relationship Based on Geo Economics Requirements, International Journal of Recent Technology and Engineering (IJRTE), Vol. 7, Issue 6S5, pp. 204-206, 2019.

[24].Fenny Syafariani R., Andri Sahata Sitanggang, Eko Yudhi Pramono, Wahidah Hashim, Andino Maseleno, Systems and Services Pattern Descriptions at Daycare, International Journal of Recent Technology and Engineering (IJRTE), Vol. 7, Issue 6S5, pp. 207-212, 2019.

[25].Tri Susilowati, P. Manickam, G. Devika, K. Shankar, Latifah, Muhamad Muslihudin, Wahidah Hashim, Miftachul

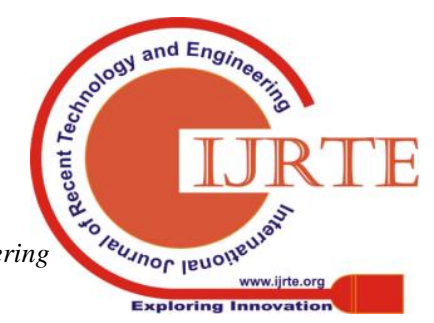




\section{Boarding House Selection using SAW Method}

Huda, Aleksandr Aleeksevich Korostelev, Andino Maseleno, Decision Support System for Determining Lecturer Scholarships for Doctoral Study Using CBR (Case-Based Reasoning) Method, International Journal of Recent Technology and Engineering (IJRTE), 2019. pp. 3281-3290.

[26]. Muhamad Muslihudin, M. Ilayaraja, K. Sathesh Kumar, K. Shankar, Jauharotun Jamilah, Dita Novitasari, Miftachul Huda, Wahidah Hashim, Irina V. Rudenko, Andino Maseleno, Decision Support System in Kindergarten Selection using TOPSIS Method, International Journal of Recent Technology and Engineering (IJRTE), 2019. pp.3291-3298.

[27]. Muhamad Muslihudin, G. Devika, P. Manickam, K. Shankar, Dian Permana Putra, Eki Pramudia Sukarno Putra, Miftachul Huda, Wahidah Hashim, Oksana P. Denisova, Andino Maseleno, Expert System in Determining Baby Disease using Web Mobile-based Weighted Product Method, International Journal of Recent Technology and Engineering (IJRTE), 2019. pp.3299-3308.

[28]. Muhamad Muslihudin, K. Sathesh Kumar, M. Ilayaraja, K. Shankar, Lailaturrohmah, Dian Permana Putra, Wahidah Hashim, Andino Maseleno, Expert System in Determining the Quality of Nutmeg Breed using Website-Based Forward Chaining Methods, International Journal of Recent Technology and Engineering (IJRTE), 2019. pp.3309-3318.

[29]. Muhamad Muslihudin, S. Hemalatha, K. Shankar, Eswaran Perumal, Nofiyanti, Satria Abadi, Wahidah Hashim, Andino Maseleno, Application of Expert System for Determining Export Quality Pepper Seeds using Website-Based Forward Chaining Method, International Journal of Recent Technology and Engineering (IJRTE), 2019. pp. 3319-3329.

[30]. Muhamad Muslihudin, Rizky Purnama, Wahidah Hashim, Andino Maseleno, Selection of Temporary Landfill using Fuzzy Multiple Attribute, International Journal of Innovative Technology and Exploring Engineering, 2019. pp.598-604.

[31]. Muhamad Muslihudin, Siti Mukodimah, Erma Dwiyani, Trisnawati, Wahidah Hashim, Andino Maseleno, Fuzzy Logic Prediction of Dengue Hemorrhagic Fever Distribution in Pringsewu Region, International Journal of Innovative Technology and Exploring Engineering, 2019. pp.605-612.

[32].S. Senthil, B. Ayshwarya, Prediction of Lung Cancer using Blue Whale Optimizer Algorithm with Neural Network Classifier, Journal of Advanced Research in Dynamical and Control Systems, Volume 11, 02-Special Issue, 2019. pp. 1737-1748.

[33]. Mohamed Elhoseny, K. Shankar, S.K. Lakshmanaprabu, Andino Maseleno, N. Arunkumar, Hybrid Optimization with Cryptography Encryption for Medical Image
Security in Internet of Things, Neural Computing and Applications, Springer, October 2018, pp. 1-15.

[34].E. Laxmi Lydia, P. Krishna Kumar, K. Shankar, S.K. Lakshmanaprabu, R.M. Vidhyavathi, Andino Maseleno, Charismatic Document Clustering through Novel K-Means Non-negative Matrix Factorization (KNMF) Algorithm using Key Phrase Extraction, International Journal of Parallel Programming, Springer, 2018, pp. $1-19$.

[35].K. Shankar, S.K. Lakshmanaprabu, Deepak Gupta, Andino Maseleno, Victor Hugo C. De Albuquerque, Optimal feature-basedmulti-kernel SVM approach for thyroid disease classification, The Journal of Supercomputing, Springer, Vol. 74, no. 259, 2018, pp. $1-16$.

[36].Andino Maseleno, Alicia Y.C. Tang, Moamin A. Mahmoud, Marini Othman, K. Shankar, Big Data and E-Learning in Education, International Journal of Computer Science and Network Security, 2018, Vol. 18, No. 5, pp. 171- 174.

[37]. Satria Abadi, Akmal Hawi, Akla, Ihsan Dacholfany, Miftachul Huda, Kamarul Shukri Mat Teh, Jaki Walidi, Wahidah Hashim, Andino Maseleno, Identification of Sundep, Leahopper and Fungus of Paddy by using Fuzzy SAW Method, International Journal of Pharmaceutical Research, Volume 11, Issue 1, January - March 2019.

[38]. Andino Maseleno, Miftachul Huda, Kamarul Azmi Jasmi,Bushrah Basiron, Ismail Mustari, Abdul Ghaffar Don, Roslee bin Ahmad, Hau-Kashyap Approach for Student's Level of Expertise, Egyptian Informatics Journal, Elsevier, Vol. 20, Issue 1, March 2019, pp. 27-32.

[39].Liang Zhou, Hesam Kamyab, Aravindhan Surendar, Andino Maseleno, Aygul Z. Ibatova, Shreeshivadasan Chelliapan, Nima Karachi, Zohreh Parsaee, Novel Z-scheme composite Ag2CrO4/NG/polyimides as high performance nano catalyst for photoreduction of $\mathrm{CO} 2$ : Design, fabrication, characterization and mechanism, Journal of Photochemistry and Photobiology A: Chemistry, Elsevier, Volume 368, 1 January 2019, pp 30-40.

[40]. Muhamad Rusliyadi, Azaharaini bin Hj. Mohd. Jamil, Marini Othman, Andino Maseleno, Ratna Tri Kumalasari, Agricultural Extension Policy, Agricultural Growth and Poverty Reduction in Indonesia, International Journal of Engineering and Technology (UAE), Vol. 7, No. 4, 2018, pp. 5539-5550. 